\title{
Rir das solenidades da origem: ou o inesperado da pesquisa em educação
}

\author{
André Marcio Picanço Favacho \\ Universidade do Estado de Minas Gerais
}

\section{Resumo}

Este artigo relata questões teórico-metodológicas de uma pesquisa de doutorado que aplicou a abordagem foucaultiana às Cartas Jesuíticas do século XVI. Essa pesquisa recupera noções importantes da obra de Michel Foucault como, por exemplo, genealogia, poder, saber, proveniência e emergência não como uma simples revisão de literatura, mas como uma forma de problematização do objeto que se almejou pesquisar. Com isso, fizemos de Foucault o mesmo que ele diz ter feito de Nietzsche: uma caixa de ferramentas para ajudar a pensar um problema que o próprio filósofo não havia pensado. Dessa maneira, este artigo procura mostrar como o autor da tese pensou uma história da educação do tipo genealógica, a partir da seguinte interrogação: com qual pedagogia se educava o aprendiz no Ocidente antes da "descoberta" do Brasil e como tal pedagogia pôde ser aplicada, negada e atualizada na colônia brasileira, no confronto entre jesuítas, europeus e índios? Explicita-se a noção de recolhimento do filho do outro procedimento utilizado pelos jesuitas para recrutar e educar os filhos dos gentios da América portuguesa no século XVI. Metodologicamente, mostram-se as regularidades discursivas/enunciativas das cartas jesuíticas (principalmente os relatos do Padre Manuel da Nóbrega), o que significou tomá-las como algo que cruza, um domínio de estruturas e de unidades possiveis e que faz com que apareçam como conteúdos concretos no tempo e no espaço. Ou seja, verificou-se como, em tais cartas, se impunha nas práticas educativas do século XVI certo procedimento acerca do ato de ensinar.

\section{Palavras-chave}

Jesuítas - Genealogia foucaultiana - Recolhimento - Discurso pedagógico.

\footnotetext{
Correspondência:

André Marcio Picanço Favacho

R. Desemb. Tinoco, 444, apto. 102

30720-480 - Belo Horizonte - MG

E-mail: afavacho@uol.com.br
} 


\title{
Laughing at the solemnities of origin: or the unexpected of the research in education
}

\author{
André Marcio Picanço Favacho \\ Universidade do Estado de Minas Gerais
}

\begin{abstract}
The present article deals with theoretical-methodological questions of a doctoral research that applied the Foucauldian approach to the 16th-century Jesuit Letters. The research recovers important notions of Foucault's work, such as genealogy, power, knowledge, descent, and emergence, not as a simple literature survey, but as a way to problematize the object under investigation. With that, we have done of Foucault what he described having done of Nietzsche: a toolbox to help thinking about a problem that the philosopher himself did not investigate. In this way, the article seeks to show how the author devised a genealogical history of education based on the following question: what was the pedagogy with which the Western apprentice was educated before the "discovery" of Brazil, and how could this pedagogy be applied, denied, and adapted in colonial Brazil in the confrontation between Jesuits, Europeans, and Indians? It brings forward the notion of gathering someone else's child - a procedure employed by the Jesuits to recruit and educate the children of the heathen in 16th-century Portuguese America. Methodologically, it reveals the discursive/enunciative regularities of the Jesuit Letters (especially in the reports of Father Manuel da Nóbrega), which means taking them as something that crosses a domain of possible structures and unities, and thereby makes them appear as concrete contents in time and space. In other words, the study establishes how, in these letters, a given procedure for the act of teaching is imposed onto the educative practices of the 16th century.
\end{abstract}

\section{Keywords}

Jesuits - Foucauldian genealogy - Gathering - Pedagogical discourse.

\footnotetext{
Contact:

André Marcio Picanço Favacho

R. Desemb. Tinoco, 444, apto. 102

30720-480 - Belo Horizonte - MG

E-mail: afavacho@uol.com.br
} 
Começo aqui com uma provocação de Foucault (2000b) de que a história nos ensina a "rir das solenidades da origem", pois "gosta-se de acreditar que as coisas em seu início se encontravam em estado de perfeição; que elas saíram brilhantes [...] na luz sem sombra da primeira manhã" (p. 18).

Essa provocação está na base de toda e qualquer pesquisa que pretende fazer genealogia foucaultiana, isto é, problematizar a solenidade da origem, posto que se espera o consentimento dos genealogistas com o esdrúxulo riso da história e seu consequente embaraço causado a quem faz uma investigação no campo das ciências humanas. Nesse caso, parte-se do pressuposto de que nenhum pesquisador detém um método tão seguro que forneça diretrizes para um estudo sem dor, a menos que esse método seja uma doutrina que lhe impeça de pensar por si só. Mas se, no lugar de um método imutável e universal, o pesquisador se impor um querer-saber de como as técnicas de subjetivação, em cada tempo, transformaram indivíduos em sujeitos, aí sim ele terá muito que dizer sobre seus objetos/sujeitos de pesquisa.

Assim, a origem questionada por Foucault (2000b) refere-se àquela que ignora o presente, que quer localizar a fundação da verdade; em seu lugar, defende uma origem que descobre que as coisas não possuem essência ou fundação e que sua suposta "essência foi construída peça por peça a partir de figuras que lhe eram estranhas" (p. 18). A origem que quer a fundação da verdade está contra o presente porque prefere o conforto do método e da certeza de um pensamento já pensado. Ao contrário, o presente, em Foucault, "refere-se àquelas coisas que são constituídas em nossos procedimentos correntes de modo que não nos apercebemos que têm suas raízes no passado" (Rajchman,1985). Mas sua finalidade não é a de explicar o passado ou o presente, nem mesmo tirar lições morais, nem revelar qualquer origem, nem, ainda, encontrar alternativas ou soluções para o presente, e sim localizar os perigos do presente. Como ele mesmo afırma "não quero fazer a história das soluções, e sim a genealogia dos problemas, das problematizações” (Foucault, 1984, p. 44). Ele não quer também propor imobilismo, paralisação ou conformismo, mas ativismo intenso, ou seja, quanto menos se sabe sobre o presente, mais se deve interrogá-lo, provocá-lo em suas possibilidades. 0 presente em Foucault não é, então, o agora obtuso, estúpido e claro, mas a descontinuidade por excelência, pois dele nada sabemos e, por isso, nele costuramos os mais diferentes mosaicos. Segundo o filosófico, esse também era o tema preferido de Nietzsche, para quem o presente ou a descontinuidade era, ao mesmo tempo, a narrativa dos acidentes, dos desvios, das bifurcações, dos erros, dos acasos e dos acontecimentos.

Na teorização foucaultiana, "rir das solenidades da origem" é substituir os começos naturalizados pelos começos inventados ou construídos pelos sujeitos; é sair da felicidade ou tranquilidade de um método prescrito e seguro de pesquisa cientifica em direção às turbulências das verdades; é, ainda, contrariar a si próprio ou inventar-se numa viagem um tanto perigosa, não tanto por falta de cuidados prévios, mas por desconhecer, a priori, o caminho e o ponto de chegada; é, enfım, traçar, de maneira nova, a história.

A história que tentei traçar foi a do tipo genealógica, a partir da seguinte interrogação: com qual pedagogia se educava o aprendiz no ocidente antes da "descoberta" do Brasil e como tal pedagogia pôde ser aplicada, negada e atualizada na colônia brasileira, no confronto entre jesuítas, europeus e índios? 0 meu estudo teve como objetivo, então, entender e descrever uma pedagogia que dizia respeito ao processo de recolhimento do filho do outro - procedimento usualmente utilizado pelos jesuítas para recrutar e educar os filhos dos gentios da América portuguesa no século XVI. Para tanto, fiz uma investigação sobre a chegada dos jesuitas ao Brasil nas Cartas de Nóbrega e Anchieta do período de 1549 a $1594^{1}$.

No processo de pesquisa estudei todas as cartas do período mencionado como se fossem

\footnotetext{
1. Sobre essas cartas, não cabe aqui nenhum amplo esclarecimento. Em primeiro lugar, porque são fontes primárias bem conhecidas, de fácil acesso ao público interessado, publicadas sob o título Cartas jesuíticas; em segundo lugar, porque não fiz um estudo sobre "cartas" (embora tenha lido sobre isso, não estudei os elementos de uma carta, seus diferentes modelos etc.), mas tão somente "li" cartas e nelas busquei os ditos e não ditos que eventualmente elas poderiam conter sobre uma possivel pedagogia ou discurso pedagógico do século XVI.
} 
regularidades discursivas/enunciativas, o que significou tomá-las como algo que "cruza, um domínio de estruturas e de unidades possíveis e que faz com que apareçam como conteúdos concretos no tempo e no espaço" (Foucault, 2000a, p. 99). Ou seja, verifiquei, em tais cartas, como se impunha, nas práticas educativas do século XVI, certo procedimento acerca do ato de ensinar. Para isso, experimentei alguns conceitos foucaultianos, tais como genealogia, proveniência, emergência, saber e poder, fazendo de Foucault o mesmo que ele diz ter feito de Nietzsche: uma caixa de ferramentas para ajudar a pensar um problema que o próprio filósofo não havia pensado.

\section{A genealogia foucaultiana}

André Queiroz (1999), em seu livro $O$ paradoxo das passagens, é imperativo ao dizer que a história genealógica de Foucault é uma história de invenções; "não de invenções grandiosas e sublimes, mas de mínimas e desprezíveis invenções”. Tal desprezo nada mais é, segundo o autor, do que não se deixar enganar pelos "objetos que navegam serenos às águas calmas da maturação” (p. 61), pois pensar em genealogia seria antes "enunciar o campo de forças, as relações de poder, os jogos de saberpoder, as estratégias e os mecanismos destes jogos configurando o real" (p. 61).

Certamente, a genealogia foucaultiana só pode se enunciar dessa forma porque tomou por base uma importante - senão a mais arguta - lição de Nietzsche: a verdade é uma invenção, uma ficção. E é o próprio Foucault (2002) quem advoga essa lição quando invoca o (i)mortal riso de Nietzsche: "em um determinado ponto do tempo e em um determinado lugar do universo, animais inteligentes inventaram o conhecimento" (p. 14).

É obvio que Foucault, aliado a Nietzsche, queria debochar daqueles que, a exemplo de Kant e Schopenhauer, mas também da ética cristã, ainda acreditavam no "azul celeste" da metafísica. Naturalmente, quando Foucault buscou em Nietzsche a ideia de que a verdade é uma invenção queria dizer que, diferente da metafísica, a "genealogia é cinza”, embaçada, ofuscada e desconfortável aos olhos.

Assim como Nietzsche, Foucault pretendia se opor à ideia de origem; quis, em sua homenagem, utilizar a palavra invenção (Erfindung) ao invés da palavra origem (Ursprung). Foucault esclarece que Nietzsche opunha invenção à origem, isto é, opunha Wirkliche à Ursprung. Em outras palavras, Nietzsche opunha "história efetiva" à "história metafísica"; histórias de começos inconfessáveis às histórias de origem. Contra uma história da origem, cujas características são marcadas pela vontade "de reencontrar 'o que era imediatamente', 'o aquilo mesmo' de uma imagem exatamente adequada a si" (Foucault, 2000b, p. 17), Nietzsche sugeria escutar a história, o que, de modo algum, é arrancar o véu para desnudar a verdade. Nesse caso, a verdade nada mais é do que uma política da verdade que, mesmo quando for desmistificada, continuará sendo "uma espécie de erro que tem a seu favor o fato de não poder ser refutada, sem dúvida porque o longo cozimento da história a tornou inalterável" (Nietzsche apud Foucault, 2000b, p. 19).

Ao se posicionar, como Nietzsche, do lado do "erro", Foucault (2002) procura especificar sua genealogia, uma vez que, segundo ele, não é possível aplicar, formalmente, o pensamento de Nietzsche em qualquer tese, como se ele fosse um bastião infalível. É preciso "utilizálo, deformá-lo, fazê-lo ranger, gritar”. E mesmo que "os comentadores digam se se é ou não fiel, isto não tem o menor interesse” (p. 143).

Assim, utilizando o que poderíamos chamar de desvarios nietzschianos, o filósofo estabelece os limites de sua genealogia, ao definir que a história efetiva é construída pela Herkunft e pela Entstehung, o que significa, respectivamente, proveniência e emergência, ou, em outros termos, corpo-história e saber-prática, assunto de que tratarei no próximo tópico.

Embora tais termos tenham sido utilizados primeiramente por Nietzsche, Foucault 
(2003) atribuiu a eles uma considerável materialidade ao introduzi-los no estudo sobre as relações de poder. Explica que as relações de poder devem ser entendidas como formas infınitesimais de dominação, não se referindo apenas à do Estado sobre a sociedade civil, mas também àquelas do pai sobre o filho, do filho sobre os pais, do pastor em relação ao seu rebanho, do homem sobre sua mulher, enfım, as relações cotidianas que vivenciamos e que conhecemos tão bem. Contudo, tais relações "não [podem ser concebidas] como uma espécie de relação brutal sob a forma: você faz isto, ou eu o mato. Essas não são senão situações extremas de poder" (p. 232).

De fato, as relações de poder ou de força são relações de enfrentamento, portanto, sempre reversíveis, contornáveis, modificáveis. Em Foucault (2003), “não há relações de poder que sejam completamente triunfantes e cuja dominação seja incontornável” (p. 232). Pelo contrário,

[...] suscitam necessariamente, apelam a cada instante, abrem a possibilidade a uma resistência, e é porque há possibilidade de resistência e resistência real que o poder daquele que domina tenta se manter com tanto mais força, tanto mais astúcia quanto maior for a resistência. (p. 232)

Não obstante, as relações de poder não são ações que simplesmente desaparecem no tempo quando praticadas, pois, embora guardem, de fato, alguma efemeridade, elas se transformam ao menos em saberes, em formas de nomear as coisas, o mundo e o sujeito. Produzem, por assim dizer, verdades que nada mais são do que "procedimentos que permitem a cada instante e a cada um pronunciar enunciados que serão considerados verdadeiros" (Foucault, 2003, p. 233). Seja em forma de ciência, de conhecimentos, de informações ou de saberes (mesmo desqualificados), as relações de poder, em Foucault, são as principais fontes geradoras de saber.

Embora imbricadas, as relações de poder e de saber não podem ser reduzidas uma à ou- tra. Elas não são iguais, e é por essa razão que Foucault (2000c) vai ironizar ao dizer:

Quando leio - e sei bem que ela me é atribuída - a tese de que 'saber é poder' ou 'poder é saber', eu morro de rir, pois o meu problema é precisamente estudar as suas relações. Se fossem duas coisas idênticas, eu não teria que estudar suas relações e, como resultado, eu me teria poupado um bocado de cansaço. 0 simples fato de colocar a questão de sua relação prova claramente que eu não os tenho como idênticos. (p. 331)

Se um e outro não são idênticos é porque o poder é ação sobre ação, enquanto o saber é a complexidade das inconfessadas formas pelas quais o construímos. Para Foucault, o poder é sempre relacional, ou seja, não possui uma centralidade, não é propriedade de uma classe, nem é uma ideologia ou uma determinação econômica, não está localizado e fixo em algum ou único lugar, não pertence e nem é atributo de alguém, nem é a lei do Estado. Afırmar que o poder é relacional significa dizer que ele circula em rede, que se movimenta em várias direções, que exige vários e pequenos centros de atuação, ou seja, ninguém é só vítima de um poder qualquer, pois estamos todos sempre prontos a também exercê-lo.

Já o saber goza de considerável complexidade e pode-se constatar que, ao longo de sua obra, o próprio Foucault tentou caracterizá-lo de várias formas. Segundo Nalli (2005), ele disse, em primeiro lugar, que o saber seria uma positividade, isto é, um regime discursivo que mostraria os traços, as marcas por onde uma determinada verdade se efetivou; uma espécie de a priori histórico específico de certa verdade que nos permitiria saber das coisas. Depois, preferiu ampliar essa noção para a ideia de formação discursiva, segundo a qual o saber seria um conjunto de objetos, tipos de formulação, conceitos, temas e teorias que, usados estrategicamente, definiriam o que pode e o que não pode ser dito, quem pode e quem não pode falar 
certas coisas, onde esta ou aquela coisa pode ser falada; o saber definiria uma "ordem do discurso" para todas as sociedades em suas idiossincrasias. Por fim, o filósofo vinculou o saber a uma prática discursiva, que é um conjunto de regras discursivas - e portanto morais - que o sujeito põe em movimento quando pratica o discurso e com as quais tenta capturar (recolher) o outro, impondo-lhe uma verdade. 0 saber para o filósofo não seria, portanto, uma disciplina científica, tampouco o esboço de uma verdade que atravessa os tempos, a tradição, menos ainda a soma de conhecimentos quaisquer.

Talvez possamos apostar com Nalli (2005) que, para Foucault, o saber passa pela

positividade de todo e qualquer discurso tomado como prática discursiva que, como tal, tem seu significado literal garantido pelas relações [de poder] em que tal prática está situada e a estabelecem. (p. 164)

Desse modo, o saber não é algo estático, mas formulado a partir de contingências. Tal como o poder, o saber é fugidio, embora se materialize para melhor dominar. Isso mostra a perpétua articulação entre poder e saber. Articulação que não se resume à constatação de que o poder tem necessidade de saber. Sabiamente, Foucault (1997) traz à superfície o fato de que o poder efetivamente cria objetos de saber e que, em contrapartida, o saber acarreta efeitos de poder, porque

nenhum saber é construído sem um sistema de comunicação, de registro, de acumulação, de deslocamento, que é em si mesmo uma forma de poder e que se liga a outras formas de poder. (p. 19)

A relação é perpétua, "não é possível que o poder se exerça sem saber, não é possível que o saber não engendre poder" (Foucault, 2000b, p. 142).

Sem contemporizar, a genealogia foucaultiana é a própria história efetiva - ou a história do presente -, que possui sua mate- rialidade na complexa trama entre relações de poder e de saber. E é aí que se encontra a chave para o entendimento de como as verdades são inventadas, produzidas ou forjadas.

\section{Proveniência e emergência}

Com o intuito de equacionar melhor o tema do poder e do saber em relação à proveniência e à emergência - elementos constitutivos da genealogia foucaultiana -, estabeleci para o meu estudo a seguinte premissa: as relações de poder estão diretamente relacionadas à proveniência, enquanto o regime de saber está diretamente relacionado à emergência. Isso posto, veremos separadamente essas relações e como elas se consubstanciaram no estudo que realizei.

Sendo as relações de poder ou de força o pano de fundo que alimenta a proveniência, pude dizer que elas têm seu foco centrado no corpo do sujeito e que, portanto, são ações que atingem o campo de ação do outro. Tais ações fixam esses sujeitos a determinados códigos e fazem do corpo o alvo de toda ação que se quer preservar ou construir; afınal, o corpo tem sido, há tempos, "a superfície de inscrição dos acontecimentos" (Foucault, 2000b, p. 22).

Sendo assim, a proveniência põe em jogo uma raça, um tipo social; ela constrói um tipo de pertencimento, isto é, cria um "grupo de sangue, de tradição, de ligação entre aqueles da mesma altura, da mesma baixeza" (Foucault, 2000b, p. 20). Essa é a razão pela qual os homens criam os brasões, escolhem os seus ídolos, formam suas famílias - a fim de se separarem dos demais grupos -, além, é claro, de criarem, dentro de seus próprios grupos, uma infındável categorização de pessoas, objetos e modos de proceder.

Considerei a proveniência, em termos educacionais, como uma relação de força que cuidou de inventar ou conceber duas "espécies" correlacionadas: as figuras do mestre e do aprendiz. Ambas se transformaram, gradativa e respectivamente, nas figuras do padre-professor e do aprendiz-eclesiástico, do mestre de corporação e do aprendiz de oficio e, mais recente- 
mente, do professor e do estudante, abrangendo, ainda, as figuras do inspetor, do diretor, do pedagogo e tantas outras, pertencentes, em cada tempo, a uma mesma família: a dos escolares.

Tentei especificar as práticas que foram convocadas para a invenção do aprendiz e que tipo de marcas corporais ele teve que carregar e suportar. Vi, então, que o aprendiz, desde ou principalmente na antiguidade ocidental, teve associada à sua figura a figura do animal em geral e a do animal doméstico em especial, por ser este último, pelo convívio, aquele que se afeiçoa às pessoas. Alerta-se, contudo, que de forma alguma o aprendiz foi tido ou tratado como o próprio animal, pelo contrário, faziase de tudo para que o aprendiz não tivesse um triste fim; o que se quer dizer, portanto, é que a antiguidade mencionava o comportamento e a natureza do animal a fim de mostrar ao aprendiz a diferença entre um e outro. Ora, quem nunca escutou uma voz que dissesse: "Esse menino é um burro!" ou: "Se não estudar, vai puxar carroça!” (tornar-se um burro?).

0 fato é que os castigos aplicados aos animais também foram, similarmente, impressos no corpo do aprendiz, como verdades produzidas à custa das relações de força que lhe moldaram e lhe imprimiram um formato. No Ocidente, além da marca impressa no corpo, outras tecnologias foram inventadas, como, por exemplo, a tábua de escrever, a férula, a palmatória, os pergaminhos, os cadernos, os exercícios de memorização e de repetição, a transcrição dos livros e, enfim, a escola. Se a proveniência, na genealogia foucaultiana, cria um corpo, uma "raça”, uma "espécie", nesse estudo ela criou os objetos discursivos em torno do aprendiz que ajudaram a dar existência a esse ser, cujos contornos podem ser vislumbrados na obediência devida ao mestre, na dedicação aos estudos para evitar sofrimentos futuros e na forma meticulosa com que o aprendiz deve domar os seus instintos.

A proveniência, além de pôr em evidência uma raça ou uma espécie (o aprendiz), ainda nos permite encontrar “a proliferação dos acontecimentos por meio dos quais, graças aos quais, contra os quais, eles se formaram" (Foucault, 2000b, p. 21). Isso significa dizer que a genealogia se ocupará com a exterioridade do acidente, com "os erros, as falhas na apreciação dos maus cálculos que deram o nascimento ao que existe e tem valor para nós” (p. 21).

E se o aprendiz apresenta algum valor para nós - e é certo que sim - teremos que desvendar que falhas, erros e maus cálculos porventura ocorreram sobre seu corpo para, por meio dele, se materializarem intenções não pensadas de antemão. Perguntemos, então: por que o aprendiz teve que ser comparado ao animal? Que intenções se tinha com essa prática? A razão era nada menos para que ele se apossasse dos acontecimentos de cada tempo: do palácio, da escrita, da política, da doutrina, do comércio, do valor de uso, da terra, da ciência, da tecnologia, do espaço sideral.

Tais acontecimentos incidem sobre o corpo do aprendiz e todos esperam que ele os queira e os assuma como herança. Para além disso, foi preciso, então, aplicar, entre outras coisas, as surras, as pancadas, as chicotadas, as promessas, o ascetismo, os métodos científicos, a tecnologia, com a pretensão de evitar os erros e as falhas na apreciação dos cálculos. 0 aprendiz será, no fundo, o herdeiro de uma espécie; será, ele mesmo, inventado como espécie e no seu corpo não cessarão os efeitos da proliferação de outros e novos acontecimentos, por meio dos quais, graças aos quais, contra os quais se formaram outras figuras de aprendiz. Em cada tempo, novos acontecimentos convocaram o aprendiz a ocupar o lugar de representante de uma determinada "raça" - grega, romana, cristã, burguesa, globalizada -, pois a raça, do ponto de vista estratégico, pertence mais a ele, que é o herdeiro, do que ao adulto.

Impõe-se ao aprendiz uma herança, maldita talvez, pois quem perguntou se ele a deseja? Afınal, quem decidiu que ele deveria ser o guardião de um saber? Ou de um território? Ou de um segredo? Ou de uma doutrina? Ou de uma ciência? Ou de um império? A herança 
não é maldita somente porque é imposta, mas também pela impossibilidade de ser guardada sem risco, posto que ela contém um conjunto de germes mesquinhos e inconfessáveis.

0 fato é que, pela proveniência, temos a invenção de uma espécie - de preferência forte - e, por conseguinte, vemos a proliferação dos acontecimentos que a formam e que, por fim, marcam o corpo dessa espécie por meio dos acidentes e erros de cálculo. Esse corpo, por tudo isso, revelará uma proveniência inscrita no seu

sistema nervoso, no humor e no aparelho digestivo. Má alimentação, má respiração, corpo débil e vergado daqueles cujos ancestrais cometeram erros; que os pais tomem os efeitos por causas, acreditem na realidade do além, ou coloquem o valor eterno, é o corpo das crianças que sofrerá com isto. A covardia, a hipocrisia, simples rebentos do erro; não no sentido socrático, não porque seja preciso se engajar para ser malvado, nem também porque alguém se desviou da verdade originária, mas porque o corpo traz consigo, em sua vida e em sua morte, em sua força e em sua fraqueza, a sanção de todo erro e de toda a verdade como ele traz consigo também e inversamente sua origem - proveniência. (Foucault, 2000b, p. 22)

A proveniência é, portanto, segundo o autor, "a articulação do corpo com a história", lá onde a história se inscreverá. E tal articulação - que no caso do meu estudo se remeteu à colônia brasileira - se dará lá onde o

conquistador irá escrever o corpo do outro e nele traçar a sua própria história. Fará dele 0 corpo historiado - o brasão - de seus trabalhos e de seus fantasmas. Isto será a América "Latina". (Certeau, 2002, p. 9)

Ora, o que os jesuítas fizeram, em termos educacionais, senão criar um corpo (aprendizíndio) na história brasileira? Foi inscrito no corpo dos meninos índios um regime de enuncia- ção, um mecanismo que fez falar, que produziu um saber sobre aquele que estava sob seu efeito. 0 filho do gentio passou a ser falado, avaliado, experimentado a partir de certos saberes: uns seriam conduzidos à doutrina e outros ao oficio; uns, indomesticáveis, preguiçosos, malignos, indispostos, traiçoeiros, mentirosos; outros, amáveis e inocentes. Nesse regime de enunciação começa a se definir o índio, dar-lhe corpo, alma, vontade, desejos etc. Essa enunciação ordenava a moralização do corpo do recolhido, a única coisa que, aos olhos dos portugueses, os índios eram capazes de aprender.

Na tentativa de apagar o visível pecado trazido à mostra na nudez do corpo do índio, davam-lhe as vestimentas e roupas, mostravamlhes as leis de Deus e do Direito, ensinavam-lhes o sentido do pecado e das faltas jurídicas.

Quando a moralização do corpo do índio não surtia mais efeito, o ensino passou a ser direcionado quase exclusivamente aos filhos dos colonos, para que estes servissem de exemplo. 0 pretexto dessa decisão era que, definitivamente, os filhos dos gentios não aprendiam absolutamente nada em matéria de civilidade. Em que pese essa decisão, a educação dos filhos dos gentios continuava em jogo e os jesuítas continuavam a recolhê-los.

Eis aí, talvez, o primeiro argumento que separava dois tipos de educação: uma para os civilizáveis e outra para os não civilizáveis. Essa separação pode ser a linha invisível que atua no âmbito da educação e baliza ou justifica, ainda hoje, a própria diferença entre uma educação ofertada aos ricos e outra aos pobres.

Esse regime de enunciação - fazer falar produzia nos meninos o que nomeei na minha tese de "indianização do filho do outro". Indianizar o filho do gentio é tornar o gentio índio, que é, a meu ver, o fim último da ordem pedagógica colonial. Quer dizer, ensinavam-se os meninos para que eles se transformassem, pouco a pouco, numa figura denominada índio, cujas características seriam forjadas ao longo da história.

A indianização precisava revelar os supostos saberes dos meninos índios, suas normas, 
seus acordos e suas instituições. A indianização do índio especulou os saberes em torno da sua natureza, perguntou se ele era homem ou animal, se era um homem incompleto abandonado pelo criador ou, ainda, a prova viva da existência de Deus em pleno labor.

Quando essas especulações foram sanadas, o filho do outro estava devidamente nomeado: era um índio; agora, sim, podia ser mais bem açoitado, vigiado, controlado, educado, separado em educável e não educável, em aceito e rejeitado, enfım, em civilizável e não civilizável. Uma vez constituído, é provável que $o$ ato de educar o outro no Brasil (pelo menos durante o período colonial) tenha tomado a indianização como baliza para educar as crianças. Se na colônia ainda não havia sistema escolar nem escolarização como hoje conhecemos, havia um discurso sobre a educação do índio (a indianização) que começava a alinhavar as suas vigas mestras, quais sejam, ensinar ao filho do outro como se afastar das influências domésticas e culturais próprias, a fim de conduzi-lo para uma outra relação ético-moral: o modo de ser cristão e civilizado.

Mas uma análise genealógica do tipo foucaultiana não se completa pela proveniência; exige que adentremos o mundo da emergência.

Em Foucault (2000b), a emergência é o ponto de surgimento, cujos fins são apenas o

atual episódio de uma série de submissões: o olho foi primeiramente submetido à caça e à guerra; o castigo foi alternadamente submetido à necessidade de se vingar, de excluir o agressor, de se libertar da vítima, de aterrorizar os outros. (p. 23)

Afinal, como pergunta Foucault, quem disse que o olho nasceu desde sempre para ser contemplativo e o castigo para dar o exemplo?

Enquanto o valor da proveniência se manifesta no corpo e no instinto - nesse caso, a estruturação do aprendiz, do universitário, do estudante, do aluno - o valor da emergência está no saber que se posicionará contra o cor- po, contra a espécie, contra a história; é contra no sentido de resistir - não querer ser -, mas também de confirmar (as benesses) as forças da proveniência. Contra o aprendiz-animal, por exemplo, próprio da antiguidade, nasce o aprendiz-demônio, próprio dos tempos cristãos, o que novamente não é tratar o aprendiz como demônio, mas usar o demônio para produzir um tipo de aprendiz. Ora, quem nunca escutou uma voz que dissesse: "Esse menino é uma peste, um diabinho!"? No ocidente, desde os fins do século XVIII, a emergência nascida é, por exemplo, o aprendiz-humano, o aprendiz assistido. Mais tarde nasce o aprendiz de direito, o aprendiz com suas individualidades respeitadas e com sua "bagagem" cultural preservada. Surge dai um aprendiz livre da férula e da palmatória, protegido das seduções demoníacas; ou o aprendiz obediente, dedicado, preguiçoso, malandro, burro, capeta; ou, ainda, o aprendiz angelical, diabólico, esforçado, amoroso, capetinha etc.

No entanto, o "nome final", esse ponto de surgimento de cada exemplo dado, não deve ser tomado como a emergência propriamente dita, pois ele - o nome final - é apenas o surgimento de algo que guarda uma série de submissões; a emergência é o estado das forças, o movimento que está aí, dentro do nome, esse espaço não ocupado. Ela é, enfım, esse não lugar, esse entre-lugar que está agitado pelas forças das dominações.

Enquanto a proveniência luta para criar a espécie, para erguê-la, para dar-lhe a consistência devida e o formato adequado, a emergência luta para mantê-la viva, luta contra si mesma para não desaparecer, para não se enfraquecer e para não definhar. Diz Foucault (2000b):

Contra sua lassidão ela reage, extraindo sua força desta lassidão que não deixa então de crescer, e se voltando em sua direção para abatê-la, ela vai lhe impor limites, suplícios, macerações, fantasiá-la de um valor moral e assim por sua vez se revigorar. Este é o movimento pelo qual nasce o ideal ascético 'no instinto de uma vida em degenerescência que luta por sua existência'. (p. 24) 
Não esperemos da emergência nenhuma compaixão ao corpo, nenhuma paz que suprima de vez as dominações. Até porque se, de fato, a emergência se aproxima do saber, é preciso dizer que, sobre ele, não há mesmo um ponto final, um Absoluto. É isso, aliás, que explica a dificuldade de Foucault em nomear ou dar um único sentido para o saber; daí por que, em nenhum momento, o saber foi considerado pelo filósofo como positivo ou negativo, nem teve uma unidade, uma finalização, um encerramento. A emergência não é um cessar das dominações, não é dizer: agora chegamos ao modelo ideal de aprendiz, como o aprendiz bem-educado, por exemplo. Não! A emergência é o "efeito das substituições, reposição e deslocamentos, conquistas disfarçadas, inversões sistemáticas" (Foucault, 2000b, p. 26); não é nem a espécie pura, nem o novo nome que surge; é o turbilhão que gira entre um e outro.

Um dos recursos mais utilizados pelos jesuítas na invenção de um saber sobre o índio era alertar os curumins sobre a personalidade indígena indesejável. Diagnosticava Nóbrega (apud Serafim, 1940):

\section{[...] ter pouco constância... (p. 40-41)}

[...] mui ocasionada para mal, e assim se fará adiante se assim parecer a V. P. daquelas de que se tiver boa esperança, desde que cheguem à idade do perigo, e assim se fará troca, que do recolhimento nos mandarão os mal dispostos dos corpos, e de cá os da alma. (p. 59)

Desde que fui entendendo por experiência o pouco que se podia fazer nesta terra na conversão do gentio, por falta de não serem sujeitos, e ela ser uma maneira de gente de condição mais de feras bravas que de gente racional, e ser gente servil que se quer por mêdo e sujeição. (p. 68) E são tão cruéis e bestiais, que assim matam aos que nunca lhes fizeram mal, clérigos, frades, mulheres de tal parecer, que os brutos animais se contentariam delas e lhes não fariam mal. (p. 76)

Mas são estes tão carniceiros de corpos humanos, que sem excepção de pessoas, a to- dos matam e comem, e nenhum beneficio os inclina nem abstem de seus maus costumes, antes parece e se vê por experiência, que se ensoberbecem e fazem piores, com afagos e bom tratamento. (p. 76)

Porque doutrina maneira não se podem doutrinar nem sujeitar nem metê-los em ordem e os Índios estão metendo-se no jugo de boa vontade, sed turba quae nescit legem e não têm misericórdia nem piedade, e têm para si que estes não têm alma, nem atentam o que custaram, não o sentido senão e qualquer seu interêsse. (p. 81)

É óbvio que essa "personalidade indígena", esse corpo na história, esse saber sobre esse corpo só podiam ser alterados por meio da educação da nova geração (a criança), que deveria se "sujeitar e fazê-la viver como criaturas que são racionais, fazendo-lhe guardar a lei natural” (p. 75).

Eis o índio - um corpo de um aprendiz nos trópicos - que nasceu das Cartas Jesuíticas! Tinha, em geral, uma personalidade maléfica, bestial e traiçoeira. Algumas vezes, retratavamno de forma amorosa e civilizável. Era ora bom selvagem, ora besta sem alma, ora anjo, ora demônio. Ou melhor: os índios eram demônios que apresentavam sinais de arrependimento, ao buscar a luz e a verdade de Deus. Deduz-se, portanto, que a maior compaixão que os jesuítas tinham pelos gentios não era por serem escravizados pelos colonos, mas pelo fato de eles perceberem que os índios deveriam transpor o estado de natureza e não o faziam, acontecimento já obliterado pelos civilizados.

É notório que o ensino ao índio combinava, ao mesmo tempo, a intenção de um discurso (transformar os índios em cristãos e civilizados), a sua materialidade (o recolhimento ou colégio como locus de fortificação contra a cultura doméstica dos pais) e a produção de um sujeito (o índio como personagem que se construía de preferência na infância, a qual se tornaria objeto do ato de ensinar).

Engana-se quem pensa que o discurso pedagógico da época ensinava aos meninos ape- 
nas a arte de civilizá-los; ele criava as condições subjetivas da identidade indígena, que era tida por maligna, já que, para os jesuítas, sem mais sucesso em sua missão, o sujeito "índio" era um sujeito detestável, para quem se deveria pregar à "marteladas", posto que "são tão bestiais que não lhes entra no coração coisa de Deus; estão tão encarniçados em matar e comer que nenhuma outra bem-aventurança sabem desejar; pregar a estes é pregar em deserto às pedras" (Nóbrega, 1988, p. 229). E mais: "Não deis o santo aos cães, nem deiteis as pedras preciosas aos porcos” (p. 230).

Nessa direção, a genealogia - tanto no que se refere à emergência, como no que diz respeito à proveniência - não se ocupará com a potência latente às coisas, e sim com o jogo das dominações; ajustará seu foco, em cada tempo, para aquilo que o olho deverá enxergar. Ela não é a continuidade das coisas que se repetem, mas um estado de força que luta contra si mesma; ela "designa um lugar de afrontamento” (Foucault, 2000b, p. 24).

Valendo-me da noção foucaultiana de emergência, penso ter descoberto uma passagem significativa na histórica figura do aprendiz ocidental: percebi que nos tempos medievais a velha figura do aprendiz-animal foi, pouco a pouco, substituída pela figura do aprendiz-demoníaco. Se a emergência é o efeito das substituições, nesse caso o aprendiz-demônio (bem adaptado aos índios) deslocou, disfarçou, inverteu, sistematicamente, a figura de aprendiz-animal, cuidadosamente inventada pela Antiguidade. Com o demônio, o discurso pedagógico medieval modificou totalmente aquela antiga espécie, que perdeu as patas, a cauda, os dentes, enfim, a força e a agressividade. A nova espécie ganhou asas, ninho, bico e inocência, tudo isso para que se afastasse das tentações demoníacas. Se a antiguidade aplicou as surras ao aprendiz-animal, a Idade Média apresentou ao aprendiz-demoníaco o perigo do demônio católico, inculcando-lhe a economia da culpa e do pecado. Se a primeira não poupou o aprendiz das comparações com o jumento e das surras de férula, a última não cansou de aproximá-lo dos passarinhos, reforçando os cuidados necessários às inocentes criaturas. Enquanto uma sociedade o educava em qualquer lugar, a outra ofertava o aconchego dos recolhimentos ou das casas de ensino.

Esse foi mais ou menos o esquema que extraí da genealogia foucaultiana para pensar os objetos discursivos do Ocidente sobre o aprendiz, ou melhor, os objetos-discursos que emprestaram seus esforços para a construção da ordem pedagógica ocidental. Por fim, todos esses elementos que acabei de anunciar serviram como uma luva para o estudo da ordem pedagógica no Brasil colonial.

\section{Desdobramentos finais}

De forma esquemática, meu interesse de pesquisa era saber como construímos uma pedagogia na passagem do Velho para o Novo Mundo. Considerei, logicamente, a imagem (dupla) que os europeus tinham do Brasil na época: ora um paraíso perdido, de gente gentil, de vida sem pecado, ora um lugar habitado por monstros, animais endemoniados, bestas-feras, homens que jamais viram a luz (a verdade divina) e que sempre viveram nas trevas, na escuridão (inferno). Esse foi, sem dúvida, um contexto bem adequado para associar o aprendiz-índio à figura do animal-demônio. Certamente, essas imagens sobre o Brasil - previamente produzidas no Velho Mundo - voltaram-se com força e violência sobre os novos aprendizes, pois elas já gozavam do status de verdade sobre tal "espécie".

Antes de avançar, devo dizer que, a certa altura da pesquisa, perguntei-me pelo lugar, pelo espaço, onde, no Ocidente, se educavam os aprendizes. Do ponto de vista de um lugar de preparação, em especial nos tempos cristãos, eles eram educados numa espécie de casa, às vezes denominada de escola ou colégios cenobiais e episcopais. Na linguagem dos padres, dizia-se que tais "colégios", funcionavam como recolhimentos de jovens, a fim de ensinar-lhes a doutrina, alguma gramática e/ou algum oficio.

Foi, pois, em consonância com as antigas verdades sobre o que viria a ser um aprendiz 
que o velho recolhimento medieval das crianças entra, mais uma vez, em cena, dessa vez no Brasil. Assim como na Europa, o recolhimento dos jovens no Brasil iniciou-se nas casas junto às igrejas, com os padres recolhendo crianças e pedindo a ajuda dos pais - primeiro para as tarefas internas das casas de ensino e, mais tarde, para a construção dos colégios. Em ambos os continentes, por meio do recolhimento, ensinava-se o sentido do bem e do mal, apartavam-se os filhos dos pais e rejeitava-se a educação familiar. Enfım, em ambos os continentes faziam-se as coisas escolares todas do mesmo jeito, mas também de um jeito bem diferente, sobretudo porque a "escola" não tinha, para os novos recolhidos - os índios -, o menor sentido e valor. Eles desistiam dela na hora que bem entendiam ou nela permaneciam em razão de algum interesse. Somente a guerra entre europeus e índios estabeleceu, de fato, uma lógica, um sentido, um lugar, um tempo e um conteúdo para os recolhimentos do Brasil. É possível dizer que as guerras ocorridas na Colônia foram fator decisivo para que os jesuítas pudessem trazer todo o peso de milhares de anos de recolhimento para aquele pequeno instante de Colônia.

De todos os tipos de recolhimento praticados na Europa desde os primeiros anos da era cristã, o que prevaleceu no Brasil foi o ocorrido na Europa do fim do século XV: aquele recomendado pelas autoridades eclesiásticas e monárquicas para retirar os jovens europeus da perambulação. Tal recolhimento convocava o aprendiz ao ascetismo, como forma de se tornar cada vez mais puro para viver entre os homens e ser merecedor da graça de Deus. Entretanto, o problema que se apresentou na colônia brasileira era a dificuldade de alcançar os mesmos resultados europeus com os "índios"; dificuldade só resolvida com estratégias de governo especificas como, por exemplo, o aldeamento e as missões, que foram, ao mesmo tempo, estratégias de poder e de saber.

Mas como os índios permitiram o uso dessas estratégias? Eles não permitiram. Elas foram impostas e, por isso mesmo, contrapostas. Posso dizer, com um pouco de ousadia, que as contestações ou as táticas indígenas contra as estratégias do governo lusitano - vistas nas cartas jesuíticas -, foram tentativas e desistências de negociação com os europeus: perderam e ganharam batalhas, aliaram-se e/ou guerrearam a favor ou contra os europeus, contra ou a favor deles mesmos; casaram-se com os europeus, mataram-nos, amaram as novidades e odiaram os infortúnios; modificaram seus recursos linguísticos para acessar a nova linguagem, bem como confundiram os recursos linguísticos europeus com vistas a facilitar ou dificultar a comunicação, conforme a necessidade; enfim, misturaram-se, miscigenaram-se, assim como em qualquer outro tipo de encontro ou confronto. Aliás, o conjunto dessas táticas indígenas alerta-nos para não tomarmos o índio como uma figura inerte, romântica ou débil. Ele deve ser visto, conforme Monteiro (1994) e Cunha (1998) como homem na história, produtor de história, imerso nas lutas, mas que, infelizmente, "perdeu" a grande batalha.

Todo esse contexto de alianças e guerras foi decisivo para a implantação, no Brasil, das casas de ensino - os ditos recolhimentos - e, mais tarde, dos colégios. Foram essas alianças e guerras que ajudaram a construir os recolhimentos como dispositivo central que por vezes atendia tanto os interesses europeus como indígenas. Pelo estudo dessas alianças e guerras efetuei, na tese, a passagem do recolhimento, ocorrido no Ocidente, para o Brasil, afirmando que aqui ele ganhou algumas especificidades, enquanto foi mantido e alterado, preservado e transformado, conservado e aniquilado e, enfım, revigorado nas tramas linguísticas do tupi com o português. 0 fino acordo linguístico entre gentios e portugueses costurou, como nos mostra Villalta (1997) - não sem resistência as desistências e as forças dos elementos que constituíram os novos componentes da ordem pedagógica brasileira. Em outras palavras, de animal-demônio, o aprendiz, no Brasil, precisou se indianizar: nem animal, nem demônio, mas 
índio, essa figura híbrida (animal/demônio), mas também homem, talvez inacabado (como diziam os jesuitas nas suas pretensões salvacionistas).

Dessa maneira, educar uma criança "índia” era vislumbrar o próprio índio adulto/ endemoniado que precisava, na criança, ser, primeiro, criado e, depois, eliminado. Percebi que o recolhimento, ambiente educativo por excelência na colônia, não se constituía apenas em uma construção física ou material, como sugeriu Hilsdorf (2006), mas, principalmente, no recrutamento moral do filho do outro. Isso me autorizou a dizer que os recolhimentos construídos pelos jesuitas não se reduziam nem a um prédio (cabana) e nem a uma ação individual, pejorativa ou negativa dos padres. Tratava-se da emergência de uma experiência ética da forma pela qual passaríamos a educar as crianças no Brasil, pelo menos, creio eu, até o século XVIII. Mesmo sendo uma construção ética - e não apenas uma construção física -, o recolhimento não foi algo abstrato, mas uma ação concreta que se erigia localmente, nas brechas da colonização, da evangelização, das lutas dos índios contra jesuítas e colonos e das conciliações mútuas. Era um dispositivo cuja experimentação desenhava, pontilhadamente, os limites do principal discurso pedagógico quinhentista em ação na América Portuguesa, a saber: o recolhimento. Esse discurso pedagógico visava, sobretudo, a constituição moral do padre-professor, do aprendiz e de suas relações de parentesco, contribuindo para ampliar o número dos súditos submetidos ao Império Lusitano. Aliás, a introdução dos familiares dos meninos no interior dos recolhimentos foi essencial para a educação deles, pois os adultos admitidos dentro dos recolhimentos deveriam, preferencialmente, ter contraído matrimônio (pelas leis da Santa Madre Igreja) e já ter filhos; atuavam como referência familiar para as crianças. Com isso, a relação parental original dos meninos se quebrava e, em seu lugar, introduzia-se um outro equivalente simbólico: a noção de família europeia.

Portanto, os índios-casados serviam de exemplo para que os meninos obedecessem aos padres, sobretudo porque as guerras provocadas pelos brancos poderiam lhes causar dano maior. Pode-se deduzir, então, que a pedagogia adotada pelos recolhimentos (ou pelos jesuítas) não se restringia ao discurso ensino-aprendizagem da doutrina cristã, mas se ampliava para a complexidade social, abrangendo o ensino das primeiras letras, o respeito ao Estado (português) e a aceitação do modelo familiar europeu. Dessa maneira, as práticas pedagógicas ocorriam nesses quatro possíveis campos de ação. Primeiro na doutrina, porque os padres moldavam nos meninos um caráter moral-cristão; depois no ensino, porque descobriam formas específicas de ensinar o índio a ler e escrever; em seguida na autoridade temporal, porque os alertavam para a importância do Estado (na figura do rei, do governador e mesmo na dos padres), a quem deveriam necessariamente obedecer; e, por fım, na produção de uma outra noção de família, ao substituírem os amplos laços parentais dos gentios pelo modelo europeu e cristão de família nuclear (pai, mãe e filhos), guiada não mais por um homem guerreiro, mas por um pai.

Posso dizer que esses quatro campos de ação das práticas de ensino formaram a estrutura da pedagogia nascente no século XVI, a qual, como sabemos, vai requisitar, mais tarde, a escola, a Igreja, o Estado e a família para se imporem como logos do discurso pedagógico. A ordem pedagógica do século XVI nada mais foi do que a sujeição do outro à Igreja, à Justiça e ao pai, o que equivale dizer: a Deus, ao Estado e à Família. Assim, a análise das cartas jesuíticas me permitiu concluir que o recolhimento foi mais do que uma etapa dos tempos coloniais, mais do que uma arquitetura escolar e mais do que uma simples imposição dos valores europeus sobre os valores dos colonizados. Ademais, o recolhimento, nas suas diferentes estratégias de colonização, funcionou como um instrumento que produziu, nos meninos e adultos recolhidos, a própria noção de pessoa em que eles deveriam se tornar, isto é, indios. Funcionando ao lado de outras formas de aprisionamento, esse dispositivo - o recolhimento - era a estrutura ideal que o estado colonial 
carecia para estabelecer, primeiramente, uma forma especifica de capturar o outro (por meio do recolhimento físico), depois, forjar-lhe uma personalidade (a indígena) e, por fim, criar uma instituição na qual pudesse ensiná-lo a ser um súdito cristão (a eschola). Esta seria o lugar ideal para abrigar ou produzir, em especial, a moral dos "fracos"; foi nela que os "fortes" (futuros guerreiros) se transformariam em "fracos" (aprendizes).

Diferente do aprendiz-animal - aquele que era surrado -, o aprendiz-índio, no Brasil, foi inventado no exercício de paciência, na busca dos meninos pelos matos, no seu cuidado, na sua proteção e na lenta substituição do mundo adulto (índio endemoniado) por uma infância regenerada, trazida à luz, modificada em seus costumes e enfraquecida na sua vontade. Os colégios, da mesma forma, foram fundamentais para que os meninos, no processo de colonização, renascessem no corpo místico de um discurso pedagógico que se destinava a reeditá-los na versão católica. Diferentemente do que se imagina, o colégio não nasceu do humanismo dos padres, mas da negociação em face da guerra.

Resta-nos saber o quanto tudo isso ainda se prolongou para além da Colônia e contribuiu para formarmos uma espécie de ética do recolhimento. Afinal, é válido nos perguntamos: que força é essa que, no campo educacional ocidental, nos convida, a todo instante, a recolher os meninos para algum tipo de instituição sob o argumento infalível de protegê-los?

Contando dessa forma, parece que tudo foi simples ou que sempre tive o controle total da pesquisa. Ledo engano! A questão é bem outra e, sem pretensões, recorro a Nietzsche (2001):

Afundo

Um pesquisador, eu? Oh, não use a palavra!

Sou somente pesado - de muitos quilos!

Eu caio, caio sem parar E enfim chego ao fundo! (p. 44) 


\section{Referências bibliográficas}

CERTEAU, M. A escrita da história. Rio de Janeiro: Forense Universitária, 2002.

CUNHA, M. C. História dos índios no Brasil. São Paulo: Companhia das Letras, 1998.

FOUCAULT, M. A arqueologia do saber. Rio de Janeiro: Forense Universitária, 2000a.

Microfísica do poder. 15. ed. Rio de Janeiro: Graal, 2000b.

Arqueologia das ciências e história dos sistemas de pensamento. Ditos e escritos, v. 2. Rio de Janeiro: Forense Universitária, 2000c.

A verdade e as formas jurídicas. Rio de Janeiro: NAU, 2002.

A governamentalidade. Ditos e escritos, v. 4. Rio de Janeiro: Forense Universitária, 2003.

Teorias e instituições penais. Resumo dos cursos do Collège de France (1970-1982). Rio de Janeiro: Jorge Zahar, 1997.

Entrevista e conversas com Michel Foucault. In: ESCOBAR, C. (Org.). $\mathbf{0}$ dossier - últimas entrevistas. Rio de Janeiro: Livraria Taurus, 1984.

HILSDORF, M. L. S. História da educação brasileira: leituras. São Paulo: Thomson Learning, 2006.

MONTEIRO, J. M. Negros da terra: índios e bandeirantes nas origens de São Paulo. São Paulo: Companhia das Letras, 1994.

NALLI, M. A. Sobre o conceito foucaultiano de "discurso". In: ORLANDI, L. (Org.). A diferença. Campinas: Editora Unicamp, 2005.

NIETZCHE, F. A gaia ciência. São Paulo: Companhia das Letras, 2001.

NÓBREGA, M. Cartas do Brasil: 1549-1560. Belo Horizonte/São Paulo: Itatiaia/Editora da Universidade de São Paulo, 1988. (Coleção Reconquista do Brasil).

PRADO JÚNIOR, C. Formação do Brasil contemporâneo. São Paulo: Brasiliense, 1942.

QUEIROZ, A. Foucault: o paradoxo das passagens. Rio de Janeiro: Pazulin, 1999.

RAJCHMAN, J. Foucault: a liberdade da filosofia. Rio de Janeiro: Jorge Zahar, 1985.

SERAFIM, L. Novas cartas jesuíticas (de Nóbrega a Vieira). São Paulo/Rio de Janeiro/Recife/Porto Alegre: Companhia Editora Nacional, 1940.

VILLALTA. L. C. 0 que se fala e o que se lê: língua, instrução e leitura. In: SOUZA, L. M. História da vida privada no Brasil: cotidiano e vida privada na América portuguesa. São Paulo: Companhia das Letras, 1997.

Recebido em 06.10.09

Aprovado em 04.05.10

André Marcio Picanço Favacho é professor da Faculdade de Educação e do Programa de Pós-Graduação em Educação da UEMG (Mestrado), pesquisador do Núcleo de Estudos e Pesquisas sobre Formação de Professores, Trabalho Docente e Discurso Pedagógico. 